\title{
The Possible Mechanism of Physiological Adaptation to the Low-Se Diet and Its Health Risk in the Traditional Endemic Areas of Keshan Diseases
}

\author{
Qin Wang ${ }^{1} \cdot$ Shuo Zhan ${ }^{1} \cdot$ Feng Han ${ }^{1} \cdot$ Yiqun Liu ${ }^{1} \cdot$ Hongying Wu ${ }^{3} \cdot$ Zhenwu Huang $^{1,2}$ (I) \\ Received: 28 May 2021 / Accepted: 23 July 2021 / Published online: 8 August 2021 \\ (c) The Author(s), under exclusive licence to Springer Science+Business Media, LLC, part of Springer Nature 2021
}

\begin{abstract}
Selenium is an essential trace element for humans and animals. As with oxygen and sulfur, etc., it belongs to the sixth main group of the periodic table of elements. Therefore, the corresponding amino acids, such as selenocysteine (Sec), serine (Ser), and cysteine (Cys), have similar spatial structure, physical, and chemical properties. In this review, we focus on the neglected but key role of serine in a possible mechanism of the physiological adaptation to Se-deficiency in human beings with an adequate intake of dietary protein: the insertion of Cys in place of Sec during the translation of selenoproteins dependent on the Sec insertion sequence element in the 3'UTR of mRNA at the UGA codon through a novel serine-dependent pathway for the de novo synthesis of the Cys-tRNA ${ }^{[\mathrm{Ser}] \mathrm{Sec}}$, similar to Sec-tRNA ${ }^{[\mathrm{Ser}] \mathrm{Sec}}$. We also discuss the important roles of serine in the metabolism of selenium directly or indirectly via GSH, and the maintenance of selenium homostasis regulated through the methylation modification of Sec-tRNA ${ }^{[\mathrm{Ser}] \mathrm{Sec}}$ at the position $34 \mathrm{U}$ by SAM. Finally, we propose a hypothesis to explain why Keshan disease has gradually disappeared in China and predict the potential health risk of the human body in the physiological adaptation state of low selenium based on the results of animal experiments.
\end{abstract}

Keywords Serine $\cdot$ Selenium metabolism $\cdot$ Sec-tRNA ${ }^{[\mathrm{Ser}] \mathrm{Sec}} \cdot$ Selenium deficiency $\cdot$ Physical adaptation

\section{Introduction}

Selenium (Se) is an essential trace element for humans and animals due to its antioxidant and anti-inflammatory superiorities. Among the 25 selenoproteins that contain

Qin Wang and Shuo Zhan contributed equally to this paper.

Hongying Wu

hongyingwuxh@163.com

$\bowtie$ Zhenwu Huang

huangzw@ninh.chinacdc.cn

1 Department of Nutrition and Metabolism, Chinese Center for Disease Control and Prevention, National Institute for Nutrition and Health, Beijing 100050, China

2 The Key Laboratory of Micronutrients Nutrition, National Health Commission of The People's Republic of China, Beijing, China

3 Department of Radiology, Union Hospital, Tongji Medical College, Huazhong University of Science and Technology, 1277 Jiefang Rd, Wuhan 430022, Hubei Province, China selenocysteine (the twenty-first amino acid, or Sec for short), Se takes the active site. Some selenoproteins have enzymatic activity, such as glutathione peroxidases, thioredoxin reductases, and deiodinase.

$\mathrm{Se}$ is located in the sixth main group (VIA) of the periodic table of elements, as with oxygen $(\mathrm{O})$, sulfur $(\mathrm{S})$, tellurium $(\mathrm{Te})$, polonium $(\mathrm{Po})$, and livermorium $(\mathrm{Lv})$. Therefore, serine (Ser), cysteine (Cys), and selenocysteine ( $\mathrm{Sec}$ ) have similar chemical structures, as shown in Fig. 1. These amino acids can transform into each other [1,2].

Here, we firstly indroduce the sources and major metabolic pathways of serine and describe how serine participates in the metabolism of amino acids with sulfur in the biosyntheses of SAM and GSH. Next, we focus on the neglected but crucial roles of serine involving in the metabolism of selenium-containing amino acids, as well as in the biosynthesis of 25 selenoproteins. Finally, we suggest a novel hypothesis to explain the gradual disappearance of Keshan disease without Se-supplementation and its latent health risk in China presently. 
Fig. 1 The chemical structures of L-serine, L-cysteine, and L-selenocysteine. With the exception of oxygen, sulfur, and selenium at one specific site, the three amino acids have the same elements, arrangement, and three-dimensional structure

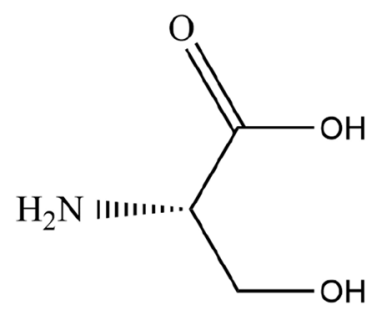

\section{The L-Serine and Its Major Metabolic Pathways}

Serine is a "nutritionally non-essential amino acid" (NNAA), being synthesized sufficiently in the human body. It can meet the needs for maximal growth and optimal health.

\section{Exogenous Serine}

The serine level is normally sufficient in a diet with any adequate source of protein. It may include Fungi (mushroom, yeast), plants (vegetables, fruits, nuts), eggs, meat like freshwater products or seafood (fish, shrimp shells), livestock (beef, mutton, pork), and poultry (chicken, duck, turkey).

Dietary proteins are ingested and absorbed in the gastrointestinal tract. The majority of exogenous serine is hydrolyzed by several digestive enzymes, e.g., epsins from the stomach and pancreatic proteases from the pancreas. These are first broken down into oligopeptides then hydrolyzed at the apical membrane of the small intestine wall [3-7] and that of the large intestine [8], where the oligopeptides are further digested into di- and tripeptides, as well as free AAs including free serine from diet. These are then transported into the enterocyte across the basolateral membrane and

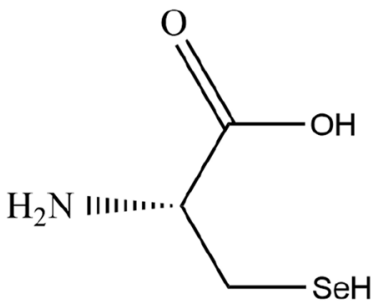

$\mathrm{SeH}$

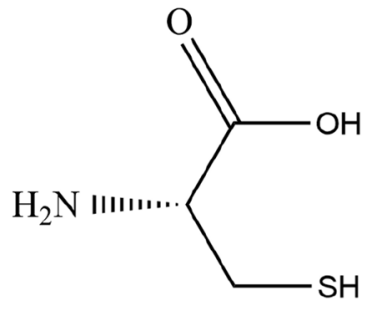

enter the portal circulation for utilization [8,9]. It is noticeable that there are different characteristics of protein digestion, absorption, and amino acid transported in vulnerable groups as in the newborns and the elderly [10-12].

\section{Two Pathways for Biosynthesis of Endogenous Serine}

Moreover, serine can also be endogenously derived from various metabolic pathways in the human body. The de novo synthesis of serine comes from the bypassing of glycolysis by three enzymes, namely, the 3-phosphoglycerate dehydrogenase (PHGDH), phosphoserine aminotransferase 1 (PSAT1), and phosphoserine phosphatase (PSPH). Serine can also be directly transformed from glycine in one step by the enzyme SHMT1/2 (Fig. 2).

\section{Major Pathways for Well-Known Physiological Roles of Serine}

Physiologically, serine plays a variety of roles, most importantly as a phosphorylation site in proteins. Besides its role in protein synthesis, serine plays a vital role in multiple cellular reactions, as the NNAA is a precursor of many important metabolites (Fig. 3). These include a one-carbon unit of the essence for the de novo synthesis of nucleotides

Fig. 2 The uptake or biosynthesis of serine via cells. This schematic diagram illustrates the transporters for exogenous serine or the pathways for synthesis of endogenous serine in mammalian cells, where the serine is a biosynthetic precursor. Modified from Ref. [13]

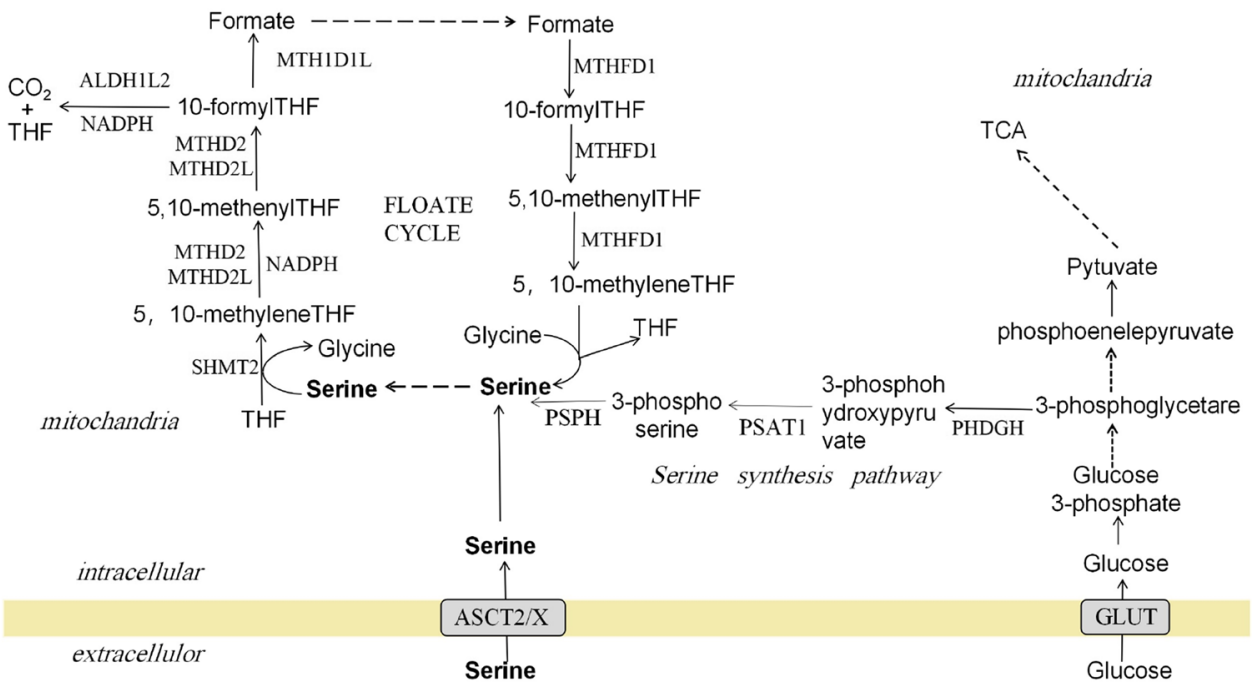


Fig. 3 The metabolic fates of serine. This schematic illustrates the products in mammalian cells where serine is a biosynthetic precursor. Modified from Ref. [14]

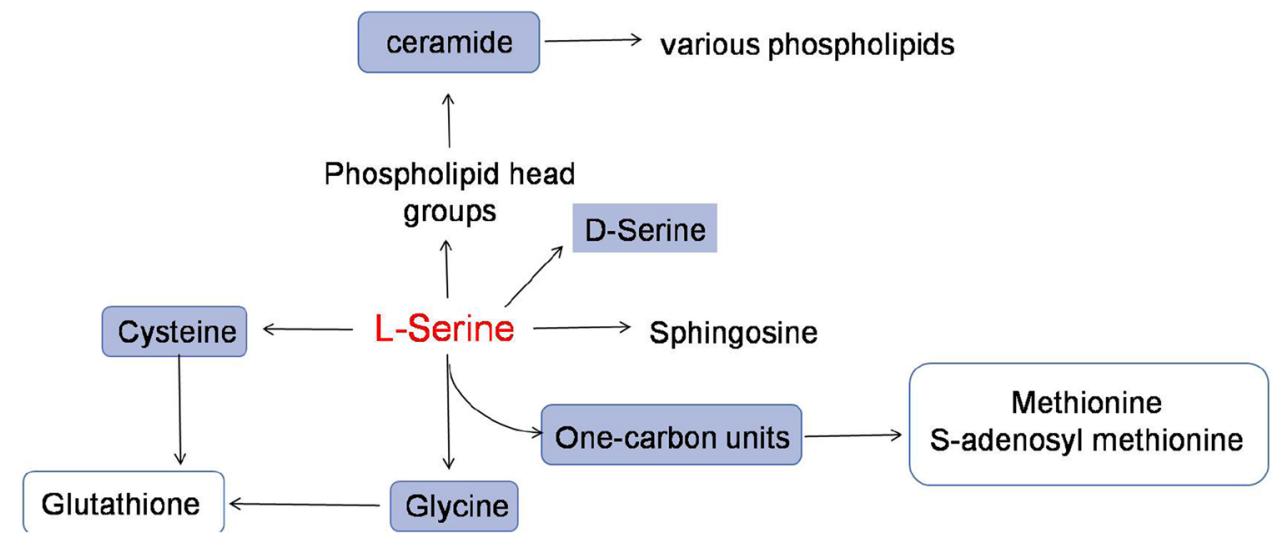

ceramide these are crucial for phospholipids and neurotransmitters, such as phosphatidylserine, D-serine, L-glycine, and L-cysteine for glutathione (GSH).

\section{D-Serine}

In the human central nervous system (CNS), D-serine is an important neurotransmitter and main endogenous co-agonist of glutamate at the glycine site of $N$-methyl-D-aspartate receptor (NMDAr) that is essential to NMDAr activation [15-18]. Not merely modulates various crucial physiological functions, it also participates in a variety of pathological processes, as NMDAr transmission, synaptic plasticity, and neurotoxicity. Endogenous D-serine is directly transformed from L-serine by serine racemase (SR) in most neural cells $[19,20]$.

It is well-documented that serine has difficulty passing through the blood-brain barrier. The brain needs to synthesize endogenous serine. In the human CNS, L-serine is predominantly biosynthesized in astrocytes from 3-phosphoglycerate through the de novo synthetic pathway and serves as a precursor for the synthesis of D-serine. The case of L-serine as well as that of L-glycine, another important neurotransmitter, is described, discussing the roles of GSH, selenite, and selenite.

Astrocytes express the enzymes available for the de novo synthesis of L-serine through the glycolysis bypass. An efficient L-serine shuttle mechanism has been found between glia and neurons for the generation of the NMDAr co-agonist D-serine. Neurons were found to be the main site for the newly synthesized D-serine $[21,22]$.

\section{One-Carbon Units Including SAM}

There is a broader set of transformations among folatemediated one-carbon units, known as the metabolism of one-carbon units, and these make them available for the syntheses of purine, thymidine, and the remethylation of homocysteine (hCys).
In the folate cycle in mammal cells, serine can be broken into L-glycine and 5, 10-methylenetetrahydro-folate $(5,10$ meTHF; a one-carbon unit), either in the reactions of the cytosol catalyzed by SHMT1 or in the mitochondria by SHMT2 [23-28]. Following this, the (5,10-meTHF) is used for the synthesis of dTMP, and 5-mTHF for hCys remethylation to reproduce Met and then SAM in the Met cycle.

\section{Phospholipids Derived from Ceramide}

De novo synthesis of ceramide occurs in the endoplasmic reticulum (ER) in mammalian cells and starts with the condensation of the active C16 fatty acid palmitoyl-CoA and L-serine by serine palmitoyltransferase (SPT) [29-32]. Ceramide is the metabolic center for sphingolipids, serving as a precursor to sphingomyelins, which are ubiquitous building blocks of mammal cell membranes [33-39].

Phospholipids constitute the main components of the cellular membrane. They are often classified into two groups: sphingolipids and phosphoglycerides, respectively containing sphingosine and glycerol. Among the later phosphoglycerides on the cellular plasma membrane, i.e., phosphatidylserine with a negatively charged head-group, abbreviated as PS, is preferentially found on the cytoplasmic leaflet and is mainly required for nerve cell membranes and myelin (especially as a neurotransmitter) [40-45]. PS is synthesized in mammalian cells by two distinct PS synthases that exchange $\mathrm{L}$-serine for choline in phosphatidylcholine (PC) or ethanolamine in phosphatidylethanolamine (PE), respectively. Because of its strong lipophilicity, PS can quickly enter the brain through the blood-brain barrier to improve the function of nerve cells, regulate the conduction of nerve impulses, and enhance the memory function of the brain [46-51].

\section{De Novo Synthesis of Glutathione}

There are several pathways to producing the endogenous $\mathrm{GSH}$, the reduced form of glutathione [52-54]. It can be 
quickly synthesized from GSSG through the GSH salvage pathway. This can occur intracellularly via the reduction of GSSG by glutathione reductase (GR) and extracellularly via $\gamma$-glutamyl transferase $(\gamma$-GT)-mediated degradation of exogenous GSH, which provides L-glutamic acid, L-cysteine, and L-glycine [52, 53]. Endogenous GSH can also be slowly de novo synthesized in a two-step reaction in the cytosol of all mammalian cells [54]. L-Glutamate and L-cysteine are catalyzed by $\gamma$-glutamylcysteine ligase (also referred to as $\gamma$-glutamylcysteine synthetase), first in an ATP-dependent manner. Following this, L-glycine is added by glutathione synthase (Fig. 4).

Exogenous or endogenous serine might be utilized for the syntheses of two endogenous AAs (L-glycine and L-cysteine) $[13,55,56]$ which are essential for the de novo biosynthesis of GSH[54]. L-Serine can be converted directly into L-glycine by the enzyme SHMT1/2[55] or utilized to produce L-cysteine through the transsulfuration metabolic pathway $[13,56]$.

\section{The Transformation of Serine into Cysteine Through Two Different Pathways}

\section{De Novo Biosynthesis of Cysteine}

It is well-known that cysteine (Cys) is not an essential amino acid since it can be synthesized from the essential amino acid methionine (Met) ingested from the diet [57-59]. The first step is the transfer of an adenosine group from ATP to Met by methionine adenosyltransferase (MAT), resulting in the formation of S-adenosylmethionine (SAM). In the second step, SAM, as the methyl donor, donates a methyl group to many molecules (such as DNA, RNA, proteins, and neurotransmitters) and is transformed into S-adenosyl homocysteine (SAH). SAH is subsequently broken down into adenosine and homocysteine (Hcy) via a reversible reaction by S-adenosyl homocysteine hydrolase (SAHH). In the transsulfuration process, with the help of vitamin $\mathrm{B}_{6}$, Hcy transfers the sulfate group to Ser catalyzed successively by cystathionine $\beta$-synthase (CBS) and cystathionine $\gamma$-lyase (CSE) and the latter is transformed into Cys (Fig. 4). Cys is one of the 20 amino acids and is commonly used in protein synthesis. Cys-tRNA can be aminoacylated directly with Cys and its genetic codons are UGU/UGC for its insertion into proteins, especially in the active cores of various important enzymes.

\section{De Novo Biosynthesis of Cys-tRNA ${ }^{\text {[Ser]Sec }}$ (Fig. 6 with Green Markers)}

Most aminoacyl-tRNAs are formed by the aminoacylation of tRNA catalyzed by aminoacyl-tRNA synthetases directly one-for-one. However, Cys-tRNA ${ }^{[\mathrm{Ser}] \mathrm{Sec}}$, a non-canonical Cys-tRNA, is now found to be formed through a novel pathway by a series of enzymes used in the biosynthesis of SectRNA $^{[\mathrm{Ser}] \mathrm{Sec}}$. Cysteine carried by Cys-tRNA ${ }^{[\mathrm{Ser}] \mathrm{Sec}}$ comes from two parts, the carbon backbone directly provided from serine and the sulfate element from hydrogen sulfide, which

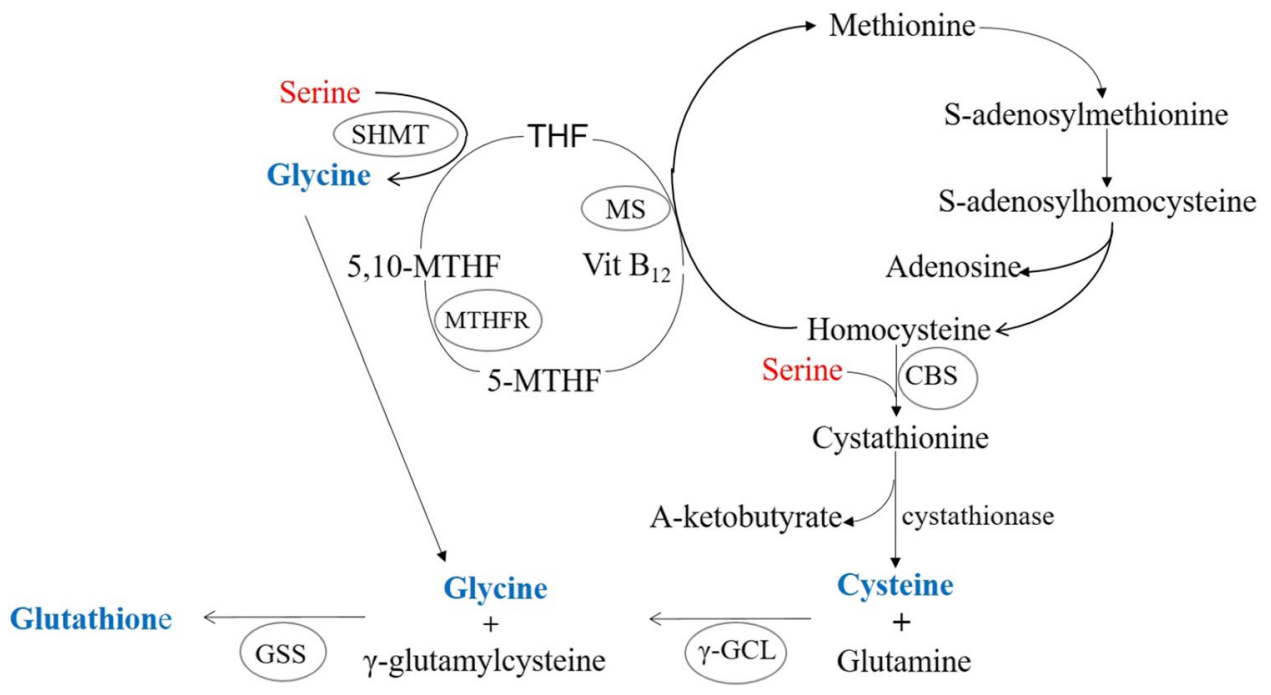

Fig. 4 The indirect role of serine in the synthesis of glutathione and cysteine. This schematic illustrates that serine is the biosynthetic precursor for the endogenous synthesis of glycine or cysteine which are essential for GSH. Cysteine can be produced by cystine rapidly and also be de novo biosynthesized by the transsulfuration process.

Modified from reference [60]. Abbreviations: $S H M T$ serine hydroxymethyltransferase, 5-MTHF 5-methyltetrahydrofolate, 5,10-MTHF 5,10-methyltetrahydrofolate, $M S$ methionine synthase, MTHFR methylenetetrahydrofolate reductase, $C B S$ cystathionine beta-synthase, $\gamma$-GCL $\gamma$-glutamylcysteine ligase, GSS glutathione synthetase 
is degenerated from several sulfur-containing compounds, including cysteine itself from protein breakdown.

\section{The Transformation of Serine into Selenocysteine Through a tRNA-Dependent Pathway}

\section{Generation of Hydrogen Selenide and H2SePO3}

There are different types of Se species in the human diet. Generally, the principal component of selenium compounds in plant foods is mainly selenomethionine (SeMet), the major selenium form in animal foods is selenocysteine (Sec), and some fungi (such as yeast) and nuts are rich in methylselenol-producing selenocompounds [61, 62]. Selenate and selenite are often used as nutritional supplements in infant formula and clinic parenteral nutritional formulae [63-65]. Any form of Se-containing compounds ingested by the human body can be metabolized to the same intermediate, $\mathrm{HSe}^{-}$directly or through methylselenol $\left(\mathrm{CH}_{3} \mathrm{SeH}\right)$ indirectly (Fig. 5). Among these Se species, serine was found to be essential during the generation of $\mathrm{HSe}^{-}$from SeMet directly or from selenate and selenite indirectly.

\section{SeMet}

As we know, Semet and Met share the same metabolic pathways: Met cycle and transsulfuration process. The metabolism of methionine (Met) starts with the Met cycle and then enters the transsulfuration pathway where Se is transferred from homocysteine (hCys) to serine, and the latter is transformed into Sec, with the help of vitamin $\mathrm{B}_{6}$ [68]. However, unlike cysteine (Cys), selenocysteine (Sec) cannot be utilized directly for the aminoacylation of tRNA to produce the Sec-tRNA for the expression of selenoproteins. Sec needs to be broken down by the specific enzyme selenocysteine lyase (Scly) into L-alanine and $\mathrm{HSe}^{-}\left(\mathrm{SeMet} \rightarrow \mathrm{Sec} \rightarrow \mathrm{HSe}^{-}\right.$) [69-71]. Historically, more attention has been paid to the effect of vitamin B6 on the catalyzation in the Scly step [72-76] rather than the essential role of serine [77].

\section{Selenate and Selenite}

In general, the content of selenate and selenite in foods is very low and the proportion is small. Selenate and selenite are usually used as nutritional supplements, or as enhancers in Se-enriched salt, for population-based intervention targeting individuals in selenium-deficient areas [78, 79]. Most of all, the authorized forms of selenium in infant formula and clinic parenteral formulae are still inorganic, including selenate and selenite. In the human body, selenate must first be reduced to selenite. Selenite then requires a large amount of GSH to produce $\mathrm{HSe}^{-}$[80-82]. In the above-mentioned GSH section, we have discussed that the two amino acids used in the synthesis of GSH, glycine, and cysteine, are often derived from serine.

\section{$\mathrm{CH}_{3} \mathrm{SeH}-$ Producing Selenocompounds}

These selenocompounds include SeMet, methylselenocysteine (MeSec), and methylselenic acid (MSA), and $\gamma$-glutamyl-Se-methylselenocysteine $(\gamma$-GMeSec). These
Fig. 5 Major sources of selenium and their metabolism in the human body. Both organic selenium (SeMet, Sec, and methyl-Sec) and inorganic selenium (selenate and selenite) from the diet or supplement are supposed to generate $\mathrm{HSe}^{-}$in the cell before the biosynthesis of selenoproteins. Modified from Ref. [67]

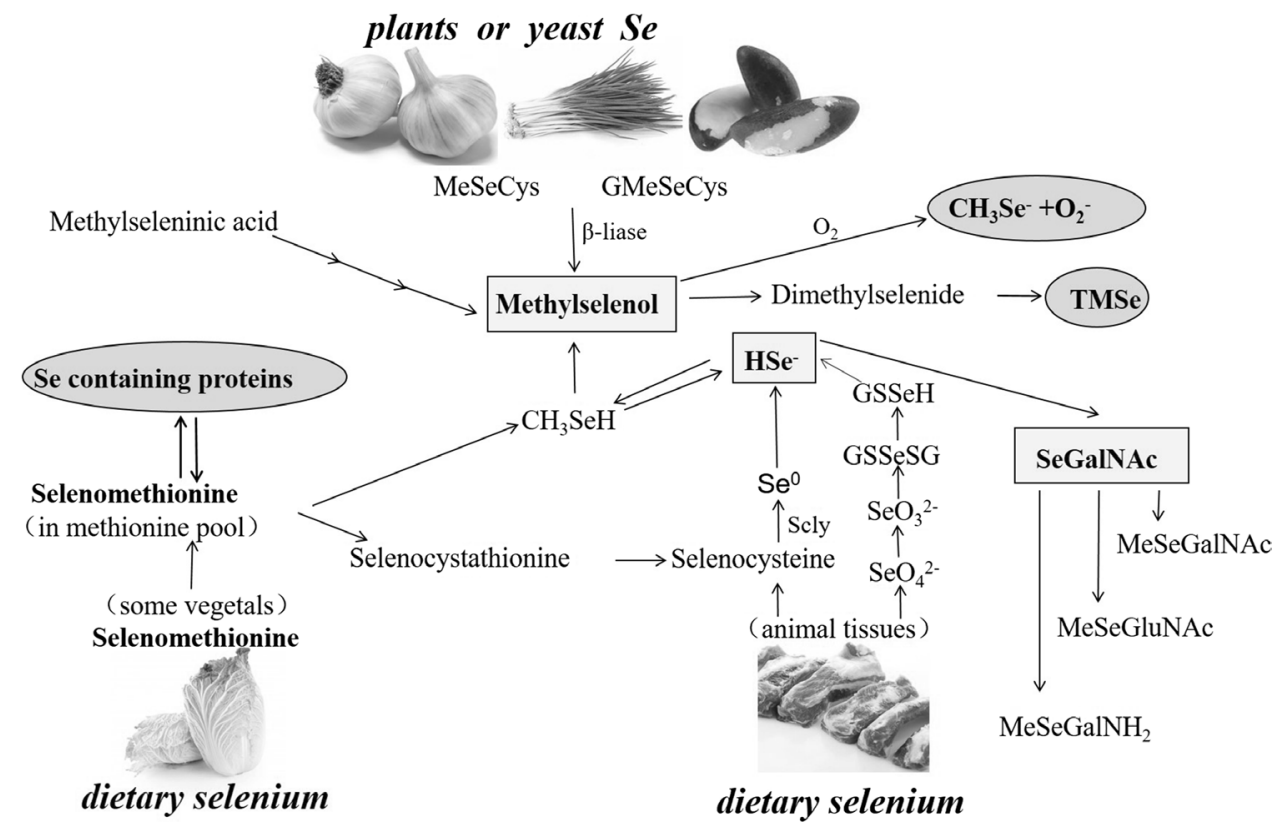


selenocompounds, except for SeMet, often produce $\mathrm{CH}_{3} \mathrm{SeH}$ by various pathways firstly: SeMet can generate $\mathrm{CH}_{3} \mathrm{SeH}$ by $\gamma$-lyase; MeSec and $\gamma$-GMeSec are transformed into $\mathrm{CH}_{3} \mathrm{SeH}$ by $\beta$-lyase; MSA is reduced to $\mathrm{CH}_{3} \mathrm{SeH}$ by GSH. And then $\mathrm{CH}_{3} \mathrm{SeH}$ is demethylated into $\mathrm{HSe}^{-}$by demethylase.

Before $\mathrm{HSe}^{-}$is used for de novo Sec synthesis, it must be phosphated to produce an active metabolite, seleophosphate $\left(\mathrm{H}_{2} \mathrm{SePO}_{3}\right)$, with ATP by seleophosphate synthetase (SEPHS2).

\section{De Novo Biosynthesis of Sec-tRNA ${ }^{[\text {Ser]Sec }}$ (Fig. 6 with Yellow Markers)}

Initially, Sec-tRNA, also called Sec-tRNA ${ }^{[\mathrm{Ser}] \mathrm{Sec}}$, is not directly loaded with the Sec amino acid but with L-serine by seryltRNA synthetase (SerRS) with the presence of ATP, resulting in an intermediate Ser-tRNA ${ }^{[\mathrm{Ser}] \mathrm{Sec}}$. Then, the Ser residue in Ser-tRNA ${ }^{[\mathrm{Ser}] \mathrm{Sec}}$ is phosphorylated by PSTK with the presence of ATP too, resulting in another intermediate O-phosposeryl-tRNA ${ }^{[\mathrm{Ser}] \mathrm{Sec}}$, abbreviated as pSertRNA $^{[\mathrm{Ser}] \mathrm{Sec}}$. Finally, O-phosphoseryl-tRNA ${ }^{[\mathrm{Ser}] \mathrm{Sec}}$ selenium transferase (SepSecS or SecS, a PLP-dependent enzyme) performs the transformation between Ser and Sec on tRNA, resulting in the generation of Sec-tRNA ${ }^{[\mathrm{Ser}] \mathrm{Sec}}$.

\section{Mature of Sec-tRNA ${ }^{[\text {Ser]Sec }}$}

The modification of bases occurs at several positions on SectRNA $^{[\mathrm{Ser}] \mathrm{Sec}}$ to generate the mature Sec-tRNA ${ }^{[\mathrm{Ser}] \mathrm{Sec}}$, especially in the single 2'-O-hydroxymethyl group at position 34 (Um34) in the wobble position of this tRNA [83-86]. In mammal animal models, the base modification in SectRNA ${ }^{[\mathrm{Ser}] \mathrm{Sec}}$ at position $34 \mathrm{U}$ can be catalyzed by the specific enzyme ALKBH8 dependent on SAM (Fig. 6), which is a most specialized final step in the maturation of Sec-tRNA ${ }^{[\mathrm{Ser}]}$
Sec, and increases the efficiency of codon reading [84-89]. Even though the molecular mechanism by which mcm5U and mcm5Um at position 34 influence the efficient recoding of UGA is presently not elucidated, the importance of this modification in selenoprotein synthesis has been inferred from the genetically modified mice [84]. Interestingly, the expression of housekeeping selenoprotein genes, such as $\operatorname{TrxR}_{1}$ and $\operatorname{TrxR}_{3}$, is dependent on mcm5U-Sec-tRNA ${ }^{[\mathrm{Ser}] \mathrm{Sec}}$ isoform, while the stress-related selenoproteins including GPX1, GPX3, SelW, SELENOW, and MSRB1 are generally synthesized by the mom5Um-Sec-tRNA ${ }^{[\mathrm{Ser}] \mathrm{Sec}}$ isoform. However, some selenoproteins including GPX4 and SELENOP can be synthesized by the two isoforms. In other words, the expressions of 25 selenoproteins are dependent on the form of Sec-tRNA ${ }^{[\mathrm{Ser}] \mathrm{Sec}}$ in response to Se-deficiency or the ROS/RNS stress in a different order of priority [83, 84, 90-94].

\section{The Underlying Mechanism of the Outbreak or Disappearance of Keshan Disease in China}

A fatal unknown disease was firstly found in the winter of 1935 in Keshan county of Heilongjiang province. It was thus renamed Keshan disease (KD). KD continued to prevail during the war. Later on, it was prevalent again in Se-deficient regions of China in the 1960s and 1970s. The acute case was characterized by a diminished heart ability to pump blood because of the enlarged and weakened left ventricle, affecting young children and women in particular [95-99].

As early as 1965, clinic researchers at Xian Medical University in China began to use selenium supplementation as a way to treat patients during the outbreak of Keshan disease. Then, Se-supplementation was demonstrated as an effective
Fig. 6 The replacement of Sec or Cys by a de novo synthesis dependent on a unique SertRNA. This schematic illustrates the de novo synthesis of Sec or Cys from Ser on tRNA with the presence of ATP. Modified from Ref. [122]

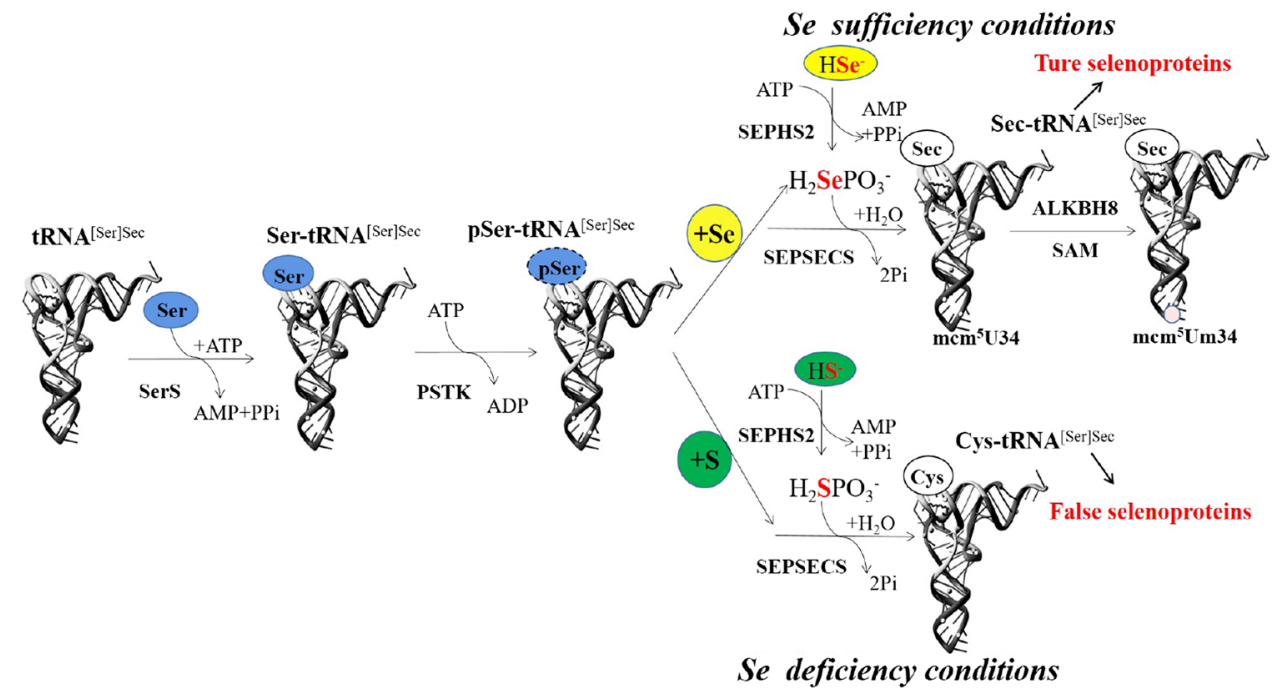


way to prevent the occurrence of KD in the Se-deficient areas around the world subsequently [100-104].

Up to now, it is well-known that KD appeared only under extremely poor Se status accompanied by environmental or host stress. The biological functions of Se are mainly exserted by selenoproteins (encoded by 25 genes in humans) [79, 105-108]. The outbreak of Keshan disease might be due to the level of Se (less than $20 \mu \mathrm{g} / \mathrm{day}$ ) in the human body, which is too low to meet the minimum expression of some housekeeping selenoprotein genes (thioredoxin reductases, including $\operatorname{TrxR}_{1}$ and $\operatorname{TrxR}_{3}$ ).

Nowadays in the Se-deficient regions in China, the amount is still less than the recommended by the Chinese Nutrition Society, though the dietary selenium intake of local residents is slowly rising. The population-based intervention strategies including the supplement of seleniumenriched salt or oral sodium selenite tablets have already been terminated since 2014, but new cases of severe diseases directly related to selenium deficiency (such as Keshan disease and Kashin Beck disease) have been rarely reported, or even disappeared [79, 109-111].

Why and how? There are two existing hypotheses. One is that the genetics of residents living in the Se-deficient areas for a long time has changed, and then they gradually adapt to their low-Se or Se-deficient diets [112]. It is known that some populations do show genetic adaptations to low selenium levels, but this cannot be expected to explain the recent reduction of selenium-related diseases. Another more likely hypothesis is that the dietary selenium intake of residents living in these Se-deficient areas is sufficient following with enough dietary protein intake or the consumption of imported Se-enriched foods [78, 113]. However, with the development of logistics, people eat a wide range of food, so timely supplement of selenium. At the same time, the animal husbandry feed has been strengthened with selenium. This might also be the main reason for the near disappearance of selenium deficiency. Therefore, relevant questions deserve further investigation in the near future.

Here, we provide a novel hypothesis about the disappearance of Keshan disease in China that there may be a physiological adaptation to the suboptimal Se status for the local residents living in the classical Se-deficient areas due to the replacement of Sec by Cys, accompanied by the daily intake of adequate dietary protein.

\section{The Dietary Se Intake of Local Residents Is More Than $17 \mu \mathrm{g} /$ Day}

From previous studies reported by a national Keshan disease research group from China in the 1970s, Keshan disease often occurred if the average dietary Se intake daily from local foods ingested by residents was less than $17 \mu \mathrm{g} /$ day and not enough to guarantee the expression of housekeeping selenoprotein genes (thioredoxin reductases, including TXNRD1 and TXNRD3) and led to the outbreak of this acute heart disease and even death [79, 107]. At present, the average dietary Se intake daily reported is increasing gradually up to more than $17 \mu \mathrm{g}$ /day followed by the daily intake of adequate dietary protein [114-116], which is at least sufficient for the minimum expression of housekeeping genes in the human body, but is still much lower than the RNIs recommended by the Chinese Nutrition Society [117].

\section{The Replacement of Sec by Cys Via a Unique Ser-tRNA-Dependent Pathway at a Low-Se Status}

From above, we have learned that the transformation between Ser and Cys or Sec can often occur usually through the transsulfuration process or the tRNA-dependent pathway. Naturally, Cys is often found to replace Sec in prokaryotic cells and eukaryotic cells to synthesize similar proteins. Through genetic engineering, the Sec residue in mammal selenoenzymes (thioredoxin reductase and GPX4) was specifically replaced by Cys to generate the pseudo-selenoenzymes. It was found that these artificial enzymes still had catalytic activity, which was decreased dramatically [118]. Then, Cys was found to recode the same genetic code UGA usually for Sec and be incorporated into the corresponding position of $\mathrm{Sec}$ in the peptide chain of selenoproteins by the unique Cys-tRNA ${ }^{[\mathrm{Ser}] \mathrm{Sec}}$, biosynthesized through the Ser-tRNA-dependent pathway, to generate the pseudoselenoproteins naturally in rats at the suboptimal intake of $\mathrm{Se}$ (Fig. 6) [119-121]. However, this replacement of Sec by Cys in the peptide chain of selenoproteins needs to be confirmed directly in local residents living in the classical Se-deficient areas in China in further studies.

\section{The Dietary Protein Intake Sufficient for the Basic Requirement of Local Residents}

As an essential element, Se exserted the important biological functions mainly by selenoproteins. Therefore, in addition to selenocysteine, like other structural and functional proteins in the human body, these selenoproteins need all 20 kinds of amino acids, including essential and non-essential amino acids. More than that, some Se-containing enzymes, such as GPXs and TrxRs still require the participation of GSH and Thioredoxin (Trx) to perform their biological functions. Most of all, several amino acids themselves play a very important role in the metabolism of Se, the replacement of Sec by Cys through the de novo biosynthesis of Sec-tRNA ${ }^{[\mathrm{Ser}] \mathrm{Sec}}$ and Cys-tRNA ${ }^{[\mathrm{Ser}] \mathrm{Sec}}$, and the expression of false or true selenoprotein. 


\section{Serine}

Firstly, serine is neglected for its crucial role in the expression of true or false selenoproteins directly through the de novo biosynthesis of Sec-tRNA[Ser]Sec or Cys-tRNA[Ser] Sec. It was reported that serine had a synergistic effect with selenocompounds on the expression of selenoproteins in cells $[122,123]$ and improved the selenium nutritional status in sows and their offspring [124]. Dietary serine and sulfatecontaining amino acids are related to the nutritional status of selenium in lactating Chinese women [125]. Also, serine can promote the generation of $\mathrm{HSe}^{-}$from homocysteine through the transsulfuration pathway. Then, serine can be used as the donor of one-carbon units carried on tetrahydrofolate for the methionine cycle to produce SAM. Finally, serine can be transformed into cysteine and glycine utilized for the de novo synthesis of GSH, which is necessary for the biological function of GPXs and the metabolism of inorganic Se.

\section{Methionine}

In addition to the de novo biosynthesis of cysteine and generation of $\mathrm{SH}^{-}$, methionine is essential for the production of the unique one-carbon unit SAM. As a reactive methyl carrier, SAM is the second common enzymatic cofactor except for ATP and is well-known for its major role in epigenetics and many biosynthetic processes. More than that, SAM is crucial for the maturation of Sec-tRNA ${ }^{[\mathrm{Ser}] \mathrm{Sec}}$ and the efficiency of codon reading. Also, SAM takes part in the metabolism and is used to generate $\mathrm{CH}_{3} \mathrm{SeH}$, dimethylselenide (DMSe, $(\mathrm{CH} 3)_{2} \mathrm{Se}$ ) and trimethylselenium ion (TMSe, $(\mathrm{CH} 3)_{3} \mathrm{Se}$ ) or Se-methyl-N-acetylselenohexosamine (selenosugar, SeSUG) (Fig. 7) [126-128].

\section{Cysteine}

In addition to the direct participation in the de novo biosynthesis of GSH, cysteine can replace selenocysteine in the expression of selenoproteins through degeneration into $\mathrm{SH}^{-}$for the de novo biosynthesis of Cys-tRNA ${ }^{[\mathrm{Ser}] \mathrm{Sec}}$.

\section{Glycine, Glutamine, and Glutamate}

Both glycine and glutamine can be used to generate endogenous serine. Glycine can be transformed into serine in one step by the enzyme SHMT1/2, while glutamine participates in the second step in the metabolic bypass of glycolysis for the de novo synthesis of serine providing the amino group in the presence of vitamin $\mathrm{B}_{6}$ by the enzyme PSAT1[129, 130]. Glutamine and glutamate can be converted to each other, and glutamate is essential to generate GSH together with glycine and cysteine in the cell.

Therefore, on the basis of adequate serine from diets, the transformation of glycine and even the de novo synthetic pathway from glycolysis, adequate dietary protein may provide a higher Se intake daily to guarantee the expression of housekeeping selenoprotein genes and also a small portion of stress-responsive selenoproteins and supply enough dietary S-containing amino acids to generate Cys-tRNA ${ }^{[\mathrm{Ser}] \mathrm{Sec}}$ for the biosynthesis of false selenoproteins instead of the corresponding stress-responsive selenoproteins in local inhabitants living in the classic Se-deficient areas. This might be an underlying mechanism for the disappearance of Keshan disease in China at present [79, 109-111].
Fig. 7 The SAM-dependent generation of $\mathrm{CH}_{3} \mathrm{SeH}$ or final excretory forms of Se. This schematic illustrates the essential role in both of these metabolic pathways with the presence of ATP. Modified from Ref. [125]

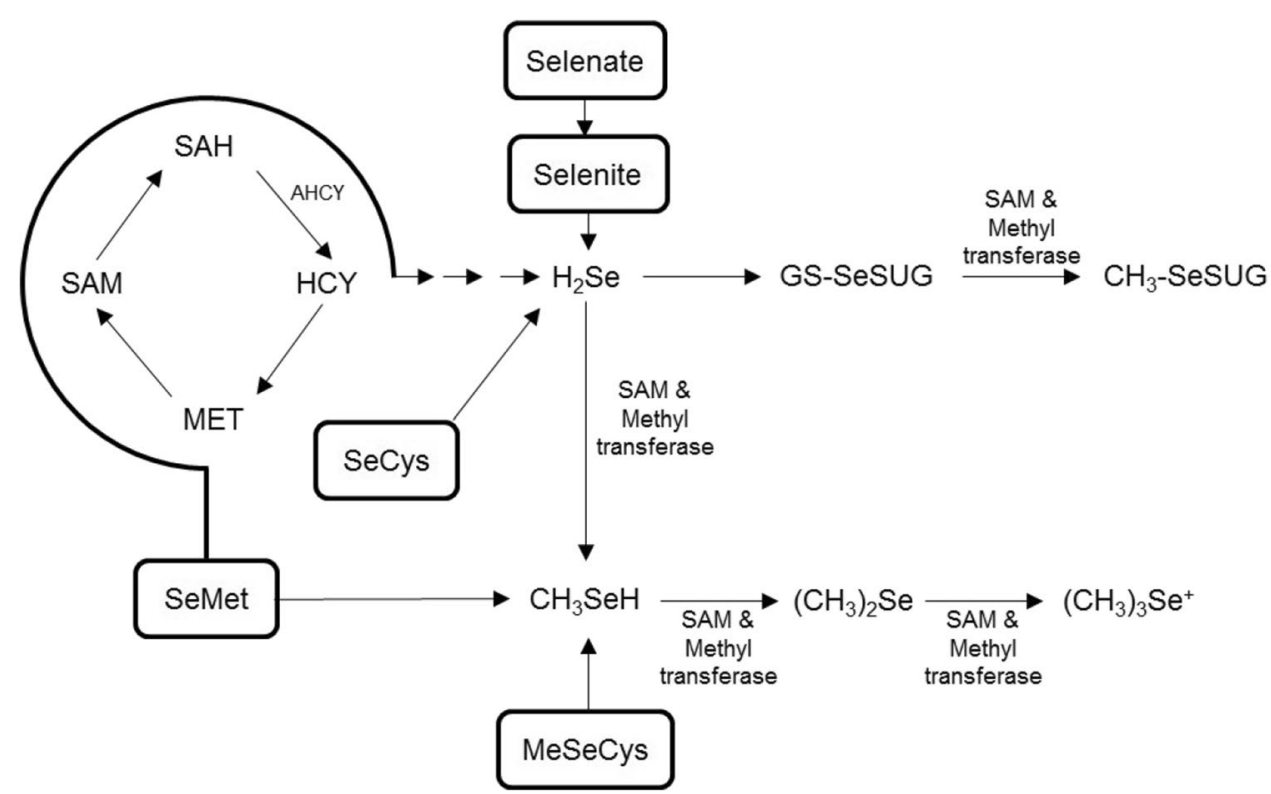




\section{The Latent Health Risk in a Case of Physiological Adaptation to a Low-Se Status}

Optimal Se intake daily is quite important to human health. Se is an essential component of several enzymes involved in various crucial metabolic pathways, which are responsible for male reproduction, thyroid hormone metabolism, antioxidant defense systems, etc.

\section{Male Subfertility}

Previous studies involving different animal models had revealed the incredible importance of Se. Selenoproteins are essentially required for spermatogenesis, antioxidant defense, and other biological functions. Nowadays, more and more studies have focused on the elucidation of crucial roles played by the peculiar and canonical selenoproteins, i.e., glutathione peroxidase 4 (GPX4) and selenoprotein P (SELENOP) in male fertility. GPX4 plays an essential role in the disulfide bond formation for spermatogenesis [131-133]. SELENOP is biosynthesized in the liver, transported in the blood. SELENOP supplies Se for the biosynthesis of GPX4 via the apolipoprotein E receptor-2 [134]. The expression of inactive GPX4 or low-active GPX4 can lead to embryonic lethality and male subfertility [135-137]. Low-Se diet $(0.15 \mathrm{mg} / \mathrm{kg})$ reduced sperm quality and testicular glutathione peroxidase-4 activity in rats [138].

\section{Hypothyroidism and Underdevelopment}

During the metabolism of thyroid hormones, iodothyronine deiodinases (DIOs) are important enzymes that are responsible for the conversion of thyroxine (T4) to triiodothyronine (T3). There are three types of DIOs with different physiological functions: DIO1 is mainly responsible for the T3 level in blood; DIO2 participates in the conversion of $\mathrm{T} 4$ to $\mathrm{T} 3$, which is the only one composed of two Se atoms; DIO3 plays roles in the transformation of $\mathrm{T} 4$ to $\mathrm{T} 3$ and $\mathrm{T} 3$ to $\mathrm{T} 2$ protecting the brain when the plasma Se is lower than $67 \mu \mathrm{g} / \mathrm{l}$, which have been connected with diminished peripheral capacity for the turning of T4 into T3. Se deficiency decreases the activity of DIOs and compromises thyroid function following by physiological and cognitive underdevelopment [139-143]. However, the results from a randomized controlled Se-supplement trial in UK elderly adults did not find the effect on thyroid function or on the ratio of T4/T3 [144, 145]. A small population survey of mothers and infants showed that the growth and development of infants were correlated with dietary selenium intake of mothers or selenium content in breast milk [146].

\section{Weak Immunobarrier}

Selenium is believed to play several roles in some key biological processes to build up the immune barrier in the human body, including antioxidant defense, redox signaling, redox homeostasis, and the immune response including regulation of $\mathrm{T}$ cell proliferation, differentiation, and metabolism, achieved through activities of selenoproteins [147-149]. For instance, reactive oxygen species (ROS) are produced, usually removed from the body by a variety of selenium-containing enzymes; otherwise, the excess of ROS usually induces oxidative stress and causes health hazards during viral or bacterial infections $[150,151]$. Recently, Se intake is sub-optimal or low and is considered one of the risk factors which might impact the outcome of SARS-CoV-2 infection [152].

\section{Short Life Expectancy}

Selenium is well known as one of the powerful antioxidants. A low level of plasma selenium was found to be associated with a higher incidence of esophageal and stomach cancer in a Chinese study [153]. Also, one study from Italy showed that the lowest quartile of plasma Se had higher mortality compared with the highest quartile of plasma Se in adults [154]. Up to now, studies on the correlation between oxidation damage and aging are still popular [155-157]. However, the results from the animal experiments are still inconsistent. Fortunately, the benefit of adequate Se intake on longevity was often confirmed in human studies [158-160].

\section{Conclusions}

Serine is a nonessential nutritional amino acid (NNAA) but its various biological functions are well known. Although selenium compounds and sulfur compounds share the same metabolic pathway, less research has focused on the key role of serine in the replacement of Sec by Cys to synthesize the pseudo-selenoproteins.

In this review, we propose several possible factors to explain why Keshan disease has gradually disappeared in China. Along with the adequate dietary proteins intake by local residents living in the classic Se-deficient areas, firstly, the low but more than $17 \mu \mathrm{g} /$ day of selenium intake can guarantee the synthesis of housekeeping selenoproteins; secondly, the replacement of Sec by Cys is inclined to synthesize some stress-responsive selenoproteins; thirdly, enough AAs is uptaken for the synthesis of serine (from glycine), 
GSH (glutamate, cysteine, and glycine), and SAM (from methionine).

We have reasons to predict the potential health risk for the human body in the physiological adaptation state of low selenium based on the results of animal experiments.

Author Contributions Respective contributions were as follows-QW and SZ: wrote the paper; FH and YQL: contributed to the conception of the work; HYW and ZWH: revised the paper critically for important content.

Funding The authors would like to thank the financial support of the National Natural Science Foundation of China under Grant Nos. 81973048, 81741032, and 81372989, the National Key Research and Development Program of China (grant number 2020YFC2006302), and the Chinese Nutrition Society Nutrition Scientific Research Fund (No. 2013-013).

Data Availability The data supporting this review are from previously reported studies and datasets, which have been cited. The processed data are available from the corresponding author upon request.

Code Availability Not applicable.

\section{Declarations}

Conflicts of interest The authors declare that they have no conflict of interest.

Ethical Approval Not applicable.

Consent to Participate Not applicable.

Consent for Publication All authors have read and approved the final manuscript.

\section{References}

1. Sheppard K, Yuan J, Hohn MJ, Jester B, Devine KM, Söll D (2008) From one amino acid to another: tRNA-dependent amino acid biosynthesis. Nucleic Acids Res 36(6):1813-1825. https:// doi.org/10.1093/nar/gkn015

2. Dery S, Reddy PS, Dery L, Mousa R, Dardashti RN, Metanis $\mathrm{N}$ (2015) Insights into the deselenization of selenocysteine into alanine and serine. Chem Sci 6(11):6207-6212. https://doi.org/ $10.1039 / \mathrm{c} 5 \mathrm{sc} 02528 \mathrm{a}$

3. Buraczewska L (1981) Absorption of amino acids in different parts of the small intestine in growing pigs. I. Absorption of free amino acids and water. Acta Physiol Pol 32(4):419-428

4. Buraczewska L (1981) Absorption of amino acids in different parts of the small intestine in growing pigs. II. Effect of addition of certain amino acids on absorption of different amino acids from acid hydrolysed casein. Acta Physiol Pol 32(4):429-436

5. Buraczewska L (1981) Absorption of amino acids in different parts of the small intestine in growing pigs. III. Absorption of constituents of protein hydrolysates. Acta Physiol Pol 32(5):569-584

6. Buraczewska L (1981) Absorption of amino acids in different parts of the small intestine in growing pigs. IV. Effect of sugars on absorption of amino acids and water. Acta Physiol Pol 32(5):585-593

7. Ten Have GA, Engelen MP, Luiking YC, Deutz NE (2007) Absorption kinetics of amino acids, peptides, and intact proteins. Int J Sport Nutr Exerc Metab 17(Suppl):S23-36

8. van der Wielen N, Moughan PJ, Mensink M (2017) Amino acid absorption in the large intestine of humans and porcine models. J Nutr 147(8):1493-1498. https://doi.org/10.3945/jn. 117.248187

9. Bröer S, Fairweather SJ (2018) Amino acid transport across the mammalian intestine. Compr Physiol 9(1):343-373. https://doi. org/10.1002/cphy.c170041

10. Milan AM, D'Souza RF, Pundir S, Pileggi CA, Thorstensen EB, Barnett MP, Markworth JF, Cameron-Smith D, Mitchell CJ (2015) Older adults have delayed amino acid absorption after a high protein mixed breakfast meal. J Nutr Health Aging 19(8):839-845. https://doi.org/10.1007/s12603-015-0500-5

11. van Goudoever JB, van der Schoor SR, Stoll B, Burrin DG, Wattimena D, Schierbeek H, Schaart MW, Riedijk MA, van der Lugt J (2006) Intestinal amino acid metabolism in neonates. Nestle Nutr Workshop Ser Pediatr Program 58:95-102; discussion $102-8$

12. Kalhan SC, Bier DM (2008) Protein and amino acid metabolism in the human newborn. Annu Rev Nutr 28:389-410. https://doi. org/10.1146/annurev.nutr.28.061807

13. Vučetić M, Cormerais Y, Parks SK, Pouysségur J (2017) The central role of amino acids in cancer redox homeostasis: vulnerability points of the cancer redox code. Front Oncol 21(7):319. https://doi.org/10.3389/fonc.2017.00319

14. Mattaini KR, Sullivan MR, Vander Heiden MG (2016) The importance of serine metabolism in cancer. J Cell Biol 214(3):249-257. https://doi.org/10.1083/jcb.201604085

15. Bardaweel SK, Alzweiri M, Ishaqat AA (2014) D-Serine in neurobiology: CNS neurotransmission and neuromodulation. Can J Neurol Sci 41(2):164-176. https://doi.org/10.1017/s031716710 001653x

16. Wolosker $\mathrm{H}$ (2018) The neurobiology of d-serine signaling. Adv Pharmacol 82:325-348. https://doi.org/10.1016/bs.apha.2017.08. 010

17. Mothet JP, Le Bail M, Billard JM (2015) Time and space profiling of NMDA receptor co-agonist functions. J Neurochem 135(2):210-225. https://doi.org/10.1111/jnc.13204

18. Neame S, Safory H, Radzishevsky I, Touitou A, Marchesani F, Marchetti M, Kellner S, Berlin S, Foltyn VN, Engelender S, Billard JM, Wolosker H (2019) The NMDA receptor activation by d-serine and glycine is controlled by an astrocytic Phgdh-dependent serine shuttle. Proc Natl Acad Sci U S A 116(41):2073620742. https://doi.org/10.1073/pnas.1909458116

19. Billard JM (2018) Changes in serine racemase-dependent modulation of NMDA receptor: impact on physiological and pathological brain aging. Front Mol Biosci 28(5):106. https://doi.org/ 10.3389/fmolb.2018.00106

20. Graham DL, Beio ML, Nelson DL, Berkowitz DB (2019) Human serine racemase: key residues/active site motifs and their relation to enzyme function. Front Mol Biosci 13(6):8. https://doi.org/10. 3389/fmolb.2019.00008

21. Wolosker H, Radzishevsky I (2013) The serine shuttle between glia and neurons: implications for neurotransmission and neurodegeneration. Biochem Soc Trans 41(6):1546-1550. https://doi. org/10.1042/BST20130220

22. Ivanov AD, Mothet JP (2019) The plastic d-serine signaling pathway: sliding from neurons to glia and vice-versa. Neurosci Lett 10(689):21-25. https://doi.org/10.1016/j.neulet.2018.05.039

23. Anderson DD, Woeller CF, Chiang EP, Shane B, Stover PJ (2012) Serine hydroxymethyltransferase anchors de novo thymidylate synthesis pathway to nuclear lamina for DNA synthesis. J Biol 
Chem 287(10):7051-7062. https://doi.org/10.1074/jbc.M111. 333120

24. Field MS, Kamynina E, Stover PJ (2016) MTHFD1 regulates nuclear de novo thymidylate biosynthesis and genome stability. Biochimie 126:27-30. https://doi.org/10.1016/j.biochi.2016.02. 001

25. Reid MA, Allen AE, Liu S, Liberti MV, Liu P, Liu X, Dai Z, Gao X, Wang Q, Liu Y, Lai L, Locasale JW (2018) Serine synthesis through PHGDH coordinates nucleotide levels by maintaining central carbon metabolism. Nat Commun 9:5442. https://doi.org/ 10.1038/s41467-018-07868-6

26. Sdelci S, Rendeiro AF, Rathert P, You W, Lin JG, Ringler A, Hofstätter G, Moll HP, Gürtl B, Farlik M, Schick S, Klepsch F, Oldach M, Buphamalai P, Schischlik F, Májek P, Parapatics K, Schmidl C, Schuster M, Penz T, Buckley DL, Hudecz O, Imre R, Wang SY, Maric HM, Kralovics R, Bennett KL, Müller AC, Mechtler K, Menche J, Bradner JE, Winter GE, Klavins K, Casanova E, Bock C, Zuber J, Kubicek S (2019) MTHFD1 interaction with BRD4 links folate metabolism to transcriptional regulation. Nat Genet 51(6):990-998. https://doi.org/10.1038/ s41588-019-0413-z

27. Wang LW, Shen H, Nobre L, Ersing I, Paulo JA, Trudeau S, Wang Z, Smith NA, Ma Y, Reinstadler B, Nomburg J, Sommermann T, Cahir-McFarland E, Gygi SP, Mootha VK, Weekes MP, Gewurz BE (2019) Epstein-barr-virus-induced one-carbon metabolism drives B cell transformation. Cell Metab 30(3):539. e11-555.e11. https://doi.org/10.1016/j.cmet.2019.06.003

28. Guiducci G, Paone A, Tramonti A, Giardina G, Rinaldo S, Bouzidi A, Magnifico MC, Marani M, Menendez JA, Fatica A, Macone A, Armaos A, Tartaglia GG, Contestabile R, Paiardini A, Cutruzzolà $F$ (2019) The moonlighting RNA-binding activity of cytosolic serine hydroxymethyltransferase contributes to control compartmentalization of serine metabolism. Nucleic Acids Res 47(8):4240-4254. https://doi.org/10.1093/nar/gkz129

29. Chang W, Hatch GM, Wang Y, Fei Y, Wang M (2019) The relationship between phospholipids and insulin resistance: from clinical to experimental studies. J Cell Mol Med 23(2):702-710. https://doi.org/10.1111/jcmm.13984

30. Wigger D, Gulbins E, Kleuser B, Schumacher F (2019) Monitoring the sphingolipid de novo synthesis by stable-isotope labeling and liquid chromatography-mass spectrometry. Front Cell Dev Biol 7:210. https://doi.org/10.3389/fcell.2019.00210

31. Parker BL, Calkin AC, Seldin MM, Keating MF, Tarling EJ, Yang P, Moody SC, Liu Y, Zerenturk EJ, Needham EJ, Miller ML, Clifford BL, Morand P, Watt MJ, Meex RCR, Peng K-Y, Lee R, Jayawardana K, Pan C, Mellett NA, Weir JM, Lazarus R, Lusis AJ, Meikle PJ, James DE, de Aguiar Vallim TQ, Drew BG (2019) An integrative systems genetic analysis of mammalian lipid metabolism. Nature 567(7747):187-193. https://doi.org/10. 1038/s41586-019-0984-y

32. Triebl A, Wenk MR (2018) Analytical considerations of stable isotope labelling in lipidomics. Biomolecules 8(4):151. https:// doi.org/10.3390/biom8040151

33. Yang Y, Lee M, Fairn GD (2018) Phospholipid subcellular localization and dynamics. J Biol Chem 293(17):6230-6240. https:// doi.org/10.1074/jbc.R117.000582

34. Balla T, Kim YJ, Alvarez-Prats A, Pemberton J (2019) Lipid dynamics at contact sites between the endoplasmic reticulum and other organelles. Annu Rev Cell Dev Biol 6(35):85-109. https:// doi.org/10.1146/annurev-cellbio-100818-125251

35. Balla T, Sengupta N, Kim YJ (2020) Lipid synthesis and transport are coupled to regulate membrane lipid dynamics in the endoplasmic reticulum. Biochim Biophys Acta Mol Cell Biol Lipids. https://doi.org/10.1016/j.bbalip.2019.05.005

36. Bandet CL, Tan-Chen S, Bourron O, Le Stunff H, Hajduch E (2019) Sphingolipid metabolism: new insight into ceramide-induced lipotoxicity in muscle cells. Int J Mol Sci. https://doi.org/10.3390/ijms20030479

37. Hussain G, Wang J, Rasul A, Anwar H, Imran A, Qasim M, Zafar S, Kamran SKS, Razzaq A, Aziz N, Ahmad W, Shabbir A, Iqbal J, Baig SM, Sun T (2019) Role of cholesterol and sphingolipids in brain development and neurological diseases. Lipids Health Dis 18(1):26. https://doi.org/10.1186/ s12944-019-0965-z

38. Olsen ASB, Færgeman NJ (2017) Sphingolipids: membrane microdomains in brain development, function and neurological diseases. Open Biol. https://doi.org/10.1098/rsob.170069

39. Parveen F, Bender D, Law SH, Mishra VK, Chen CC, Ke LY (2019) Role of ceramidases in sphingolipid metabolism and human diseases. Cells. https://doi.org/10.3390/cells8121573

40. Vance JE, Tasseva G (2013) Formation and function of phosphatidylserine and phosphatidyl-ethanolamine in mammalian cells. Biochim Biophys Acta 1831(3):543-554. https://doi.org/ 10.1016/j.bbalip.2012.08.016

41. Miyata N, Watanabe Y, Tamura Y, Endo T, Kuge O (2016) Phosphatidylserine transport by Ups2-Mdm35 in respirationactive mitochondria. J Cell Biol 214(1):77-88. https://doi.org/ 10.1083/jcb.201601082

42. Lemke G (2017) Phosphatidylserine is the signal for TAM receptors and their ligands. Trends Biochem Sci 42(9):738748. https://doi.org/10.1016/j.tibs.2017.06.004

43. Vance JE (2018) Historical perspective: phosphatidylserine and phosphatidylethanolamine from the 1800 s to the present. J Lipid Res 59(6):923-944

44. Burstyn-Cohen T, Maimon A (2019) TAM receptors, phosphatidylserine, inflammation, and cancer. Cell Commun Signal 17(1):156. https://doi.org/10.1186/s12964-019-0461-0

45. Tadini-Buoninsegni F, Mikkelsen SA, Mogensen LS, Molday RS, Andersen JP (2019) Phosphatidylserine flipping by the P4-ATPase ATP8A2 is electrogenic. Proc Natl Acad Sci U S A 116(33):16332-16337. https://doi.org/10.1073/pnas.19102 11116

46. Kim H-Y, Huang BX, Spector AA (2014) Phosphatidylserine in the brain: metabolism and function. Prog Lipid Res. https://doi. org/10.1016/j.plipres.2014.06.002

47. Hopiavuori BR, Agbaga MP, Brush RS, Sullivan MT, Sonntag WE, Anderson RE (2017) Regional changes in CNS and retinal glycerophospholipid profiles with age: a molecular blueprint. J Lipid Res 58(4):668-680. https://doi.org/10.1194/jlr.M070714

48. Che H, Fu X, Zhang L, Gao X, Wen M, Du L, Xue C, Xu J, Wang Y (2018) Neuroprotective effects of $n-3$ polyunsaturated fatty acid-enriched phosphatidylserine against oxidative damage in PC12 cells. Cell Mol Neurobiol 38(3):657-668. https://doi.org/ 10.1007/s10571-017-0516-y

49. Ojo JO, Algamal M, Leary P, Abdullah L, Mouzon B, Evans JE, Mullan M, Crawford F (2019) Converging and differential brain phospholipid dysregulation in the pathogenesis of repetitive mild traumatic brain injury and Alzheimer's disease. Front Neurosci 19(13):103. https://doi.org/10.3389/fnins.2019.00103

50. Rodríguez-Berdini L, Caputto BL (2019) Lipid metabolism in neurons: a brief story of a novel c-Fos-dependent mechanism for the regulation of their synthesis. Front Cell Neurosci 7(13):198. https://doi.org/10.3389/fncel.2019.00198

51. Klevebro S, Juul SE, Wood TR (2020) A more comprehensive approach to the neuroprotective potential of long-chain polyunsaturated fatty acids in preterm infants is needed-should we consider maternal diet and the n-6: n-3 fatty acid ratio? Front Pediatr 10(7):533. https://doi.org/10.3389/fped.2019.00533

52. Bachhawat AK, Kaur A (2017) Glutathione degradation. Antioxid Redox Signal 27(15):1200-1216. https://doi.org/10.1089/ ars.2017.7136 
53. Bachhawat AK, Yadav S (2018) The glutathione cycle: glutathione metabolism beyond the $\gamma$-glutamyl cycle. IUBMB Life 70(7):585-592. https://doi.org/10.1002/iub.1756

54. Lu SC (2013) Glutathione synthesis. Biochim Biophys Acta 1830(5):3143-3153. https://doi.org/10.1016/j.bbagen.2012.09. 008

55. Minich DM, Brown BI (2019) A review of dietary (phyto)nutrients for glutathione support. Nutrients. https://doi.org/10.3390/ nu11092073

56. Selvarajah B, Azuelos I, Platé M, Guillotin D, Forty EJ, Contento G, Woodcock HV, Redding M, Taylor A, Brunori G, Durrenberger PF, Ronzoni R, Blanchard AD, Mercer PF, Anastasiou D, Chambers RC (2019) mTORC1 amplifies the ATF4-dependent de novo serine-glycine pathway to supply glycine during TGF$\beta 1$-induced collagen biosynthesis. Sci Signal. https://doi.org/10. 1126/scisignal.aav3048

57. Jahoor F, Badaloo A, Reid M, Forrester T (2006) Sulfur amino acid metabolism in children with severe childhood undernutrition: cysteine kinetics. Am J Clin Nutr 84(6):1393-1399. https:// doi.org/10.1093/ajen/84.6.1393

58. Jahoor F, Badaloo A, Reid M, Forrester T (2006) Sulfur amino acid metabolism in children with severe childhood undernutrition: methionine kinetics. Am J Clin Nutr 84(6):1400-1405. https://doi.org/10.1093/ajcn/84.6.1400

59. Green CO, Badaloo AV, Hsu JW, Taylor-Bryan C, Reid M, Forrester T, Jahoor F (2014) Effects of randomized supplementation of methionine or alanine on cysteine and glutathione production during the early phase of treatment of children with edematous malnutrition. Am J Clin Nutr 99(5):1052-1058. https://doi.org/ 10.3945/ajcn.113.062729

60. Al MF (2020) Hyperhomocysteinemia: clinical insights. J Cent Nerv Syst Dis 9(12):1179573520962230. https://doi.org/10. $1177 / 1179573520962230$

61. Rayman MP (2008) Food-chain selenium and human health: emphasis on intake. Br J Nutr 100(2):254-268. https://doi.org/ 10.1017/S0007114508939830

62. Rayman MP, Infante HG, Sargent M (2008) Food-chain selenium and human health: spotlight on speciation. Br J Nutr 100(2):238253. https://doi.org/10.1017/S0007114508922522

63. Daniels L, Gibson R, Simmer K (1996) Randomised clinical trial of parenteral selenium supplementation in preterm infants. Arch Dis Child Fetal Neonatal Ed 74(3):F158-164

64. Johnson CE, Smith AM, Chan GM, Moyer-Mileur LJ (1993) Selenium status of term infants fed human milk or selenite-supplemented soy formula. J Pediatr 122(5 Pt 1):739-741

65. Temple KA, Smith AM, Cockram DB (2000) Selenate-supplemented nutritional formula increases plasma selenium in hemodialysis patients. J Ren Nutr 10(1):16-23

66. Navarro-Alarcon M, Cabrera-Vique C (2008) Selenium in food and the human body: a review. Sci Total Environ 400(1-3):115141. https://doi.org/10.1016/j.scitotenv.2008.06.024

67. Wiesner-Reinhold M, Schreiner M, Baldermann S, Schwarz D, Hanschen FS, Kipp AP, Rowan DD, Bentley-Hewitt KL, McKenzie MJ (2017) Mechanisms of selenium enrichment and measurement in brassicaceous vegetables, and their application to human health. Front Plant Sci 3(8):1365. https://doi.org/10.3389/fpls. 2017.01365

68. Gregory JF, DeRatt BN, Rios-Avila L, Ralat M, Stacpoole PW (2016) Vitamin B6 nutritional status and cellular availability of pyridoxal 5'-phosphate govern the function of the transsulfuration pathway's canonical reactions and hydrogen sulfide production via side reactions. Biochimie 126:21-26. https://doi.org/10. 1016/j.biochi.2015.12.020

69. Seale LA, Ha HY, Hashimoto AC, Berry MJ (2018) Relationship between selenoprotein $\mathrm{P}$ and selenocysteine lyase: insights into selenium metabolism. Free Radic Biol Med 1(127):182-189. https://doi.org/10.1016/j.freeradbiomed.2018.03.037

70. Seale LA (2019) Selenocysteine $\beta$-lyase: biochemistry, regulation and physiological role of the selenocysteine decomposition enzyme. Antioxidants (Basel) 8(9):357. https://doi.org/10.3390/ antiox 8090357

71. Seale LA, Khadka VS, Menor M, Xie G, Watanabe LM, Sasuclark A, Guirguis K, Ha HY, Hashimoto AC, Peplowska K, Tiirikainen M, Jia W, Berry MJ, Deng Y (2019) Combined omics reveals that disruption of the selenocysteine lyase gene affects amino acid pathways in mice. Nutrients 11(11):2584. https://doi. org/10.3390/nu11112584

72. Yasumoto K, Iwami K, Yoshida M (1979) Vitamin B6 dependence of selenomethionine and selenite utilization for glutathione peroxidase in the rat. J Nutr 109(5):760-766. https://doi.org/10. 1093/jn/109.5.760

73. Yin SA, Sato I, Hosokawa Y, Niizeki S, Tojo H, Yamaguchi K (1991) The necessity of dietary vitamin B6 to selenium biopotency for tissue selenium and glutathione peroxidase in rats. $\mathrm{J}$ Nutr Sci Vitaminol (Tokyo) 37(5):509-516. https://doi.org/10. 3177/jnsv.37.509

74. Beilstein MA, Whanger PD (1992) Selenium metabolism and glutathione peroxidase activity in cultured human lymphoblasts. Effects of transsulfuration defects and pyridoxal phosphate. Biol Trace Elem Res 35(2):105-118. https://doi.org/10.1007/BF027 83723

75. Dalto DB, Matte J-J (2017) Pyridoxine (vitamin B6) and the glutathione peroxidase system; a link between one-carbon metabolism and antioxidation. Nutrients 9(3):189. https://doi.org/10. 3390/nu9030189

76. Dalto DB, Tsoi S, Dyck MK, Matte J-J (2018) Gene ontology analysis of expanded porcine blastocysts from gilts fed organic or inorganic selenium combined with pyridoxine. BMC Genomics 19:836. https://doi.org/10.1186/s12864-018-5237-1

77. Morrison DG, Dishart MK, Medina D (1988) Serine and methionine enhancement of selenite inhibition of DNA synthesis in a mouse mammary epithelial cell line. Carcinogenesis 9(10): 1811-1815

78. Ning Y, Wang X, Wang S, Zhang F, Zhang L, Lei Y, Guo X (2015) Is it the appropriate time to stop applying selenium enriched salt in Kashin-Beck disease areas in China? Nutrients 7(8):6195-6212. https://doi.org/10.3390/nu7085276

79. Chen J (2012) An original discovery: selenium deficiency and Keshan disease (an endemic heart disease). Asia Pac J Clin Nutr 21(3):320-326

80. Anan Y, Kimura M, Hayashi M, Koike R, Ogra Y (2015) Detoxification of selenite to form selenocyanate in mammalian cells. Chem Res Toxicol 28(9):1803-1814. https://doi.org/10.1021/acs. chemrestox.5b00254

81. Wang Y, Fang W, Huang Y, Hu F, Ying Q, Yang W, Xiong B (2015) Reduction of selenium-binding protein 1 sensitizes cancer cells to selenite via elevating extracellular glutathione: a novel mechanism of cancer-specific cytotoxicity of selenite. Free Radic Biol Med 79:186-196. https://doi.org/10.1016/j.freeradbiomed. 2014.11.015

82. Pan X, Song X, Wang C, Cheng T, Luan D, Xu K, Tang B (2019) $\mathrm{H} 2 \mathrm{Se}$ induces reductive stress in HepG2 cells and activates cell autophagy by regulating the redox of HMGB1 protein under hypoxia. Theranostics 9(6):1794-1808. https://doi.org/10.7150/ thno.31841

83. Hatfield DL, Gladyshev VN (2002) How selenium has altered our understanding of the genetic code. Mol Cell Biol 22(11):3565-3576

84. Carlson BA, Xu XM, Gladyshev VN, Hatfield DL (2005) Selective rescue of selenoprotein expression in mice lacking a highly 
specialized methyl group in selenocysteine tRNA. J Biol Chem 280(7):5542-5548. https://doi.org/10.1074/jbc.M411725200

85. Carlson BA, Moustafa ME, Sengupta A, Schweizer U, Shrimali R, Rao M, Zhong N, Wang S, Feigenbaum L, Lee BJ, Gladyshev VN, Hatfield DL (2007) Selective restoration of the selenoprotein population in a mouse hepatocyte selenoproteinless background with different mutant selenocysteine tRNAs lacking Um34. J Biol Chem 282(45):32591-32602. https://doi.org/10.1074/jbc.M7070 36200

86. Carlson BA, Lee BJ, Tsuji PA, Copeland PR, Schweizer U, Gladyshev VN, Hatfield DL (2018) Selenocysteine tRNA[Ser]Sec, the central component of selenoprotein biosynthesis: isolation, identification, modification, and sequencing. Methods Mol Biol 1661:43-60. https://doi.org/10.1007/978-1-4939-7258-6_4

87. Fu D, Brophy JA, Chan CT, Atmore KA, Begley U, Paules RS, Dedon PC, Begley TJ, Samson LD (2010) Human AlkB homolog ABH8 Is a tRNA methyltransferase required for wobble uridine modification and DNA damage survival. Mol Cell Biol 30(10):2449-2459. https://doi.org/10.1128/MCB.01604-09

88. Fu Y, Dai Q, Zhang W, Ren J, Pan T, He C (2010) The AlkB domain of mammalian ABH8 catalyzes hydroxylation of 5-methoxycarbonylmethyluridine at the wobble position of tRNA. Angew Chem Int Ed Engl 49(47):8885-8888. https://doi.org/ 10.1002/anie.201001242

89. Songe-Møller L, van den Born E, Leihne V, Vågb $\varnothing \mathrm{CB}$, Kristoffersen T, Krokan HE, Kirpekar F, Falnes PØ, Klungland A (2010) Mammalian ALKBH8 possesses tRNA methyltransferase activity required for the biogenesis of multiple wobble uridine modifications implicated in translational decoding. Mol Cell Biol 30(7):1814-1827. https://doi.org/10.1128/MCB.01602-09

90. Kim JY, Carlson BA, Xu XM, Zeng Y, Chen S, Gladyshev VN, Lee BJ, Hatfield DL (2011) Inhibition of selenocysteine tRNA[Ser]Sec aminoacylation provides evidence that aminoacylation is required for regulatory methylation of this tRNA. Biochem Biophys Res Commun 409(4):814-819. https://doi.org/ 10.1016/j.bbrc.2011.05.096

91. Endres L, Dedon PC, Begley TJ (2015) Codon-biased translation can be regulated by wobble-base tRNA modification systems during cellular stress responses. RNA Biol 12(6):603-614. https://doi.org/10.1080/15476286.2015.1031947

92. Duechler M, Leszczyńska G, Sochacka E, Nawrot B (2016) Nucleoside modifications in the regulation of gene expression: focus on tRNA. Cell Mol Life Sci 73(16):3075-3095. https://doi. org/10.1007/s00018-016-2217-y

93. Carlson BA, Gupta N, Pinkerton MH, Hatfield DL, Copeland PR (2017) The utilization of selenocysteine-tRNA[Ser]Sec isoforms is regulated in part at the level of translation in vitro. Translation (Austin) 5(1):e1314240. https://doi.org/10.1080/21690731.2017. 1314240

94. Leonardi A, Evke S, Lee M, Melendez JA, Begley TJ (2019) Epitranscriptomic systems regulate the translation of reactive oxygen species detoxifying and disease linked selenoproteins. Free Radic Biol Med 1(143):573-593. https://doi.org/10.1016/j. freeradbiomed.2019.08.030

95. Chen X, Yang G, Chen J, Chen X, Wen Z, Ge K (1980) Studies on the relations of selenium and Keshan disease. Biol Trace Elem Res 2(2):91-107. https://doi.org/10.1007/BF02798589

96. Yu WH (1982) A study of nutritional and bio-geochemical factors in the occurrence and development of Keshan disease. Jpn Circ J 46(11):1201-1207

97. Ge K, Xue A, Bai J, Wang S (1983) Keshan disease-an endemic cardiomyopathy in China. Virchows Arch A Pathol Anat Histopathol 401(1):1-15. https://doi.org/10.1007/BF00644785

98. Levander OA, Burk RF (1986) Report on the 1986 A.S.P.E.N. Research Workshop on selenium in clinical nutrition. J Parenter
Enteral Nutr 10(6):545-549. https://doi.org/10.1177/0148607186 010006545

99. Xu GL, Wang SC, Gu BQ, Yang YX, Song HB, Xue WL, Liang WS, Zhang PY (1997) Further investigation on the role of selenium deficiency in the aetiology and pathogenesis of Keshan disease. Biomed Environ Sci 10(2-3):316-326

100. Thomson CD, Burton CE, Robinson MF (1978) On supplementing the selenium intake of New Zealanders. 1. Short experiments with large doses of selenite or selenomethionine. Br J Nutr 39(3):579-587. https://doi.org/10.1079/bjn19780073

101. Robinson MF, Rea HM, Friend GM, Stewart RD, Snow PC, Thomson CD (1978) On supplementing the selenium intake of New Zealanders 2 Prolonged metabolic experiments with daily supplements of selenomethionine, selenite and fish. Br J Nutr 39(3):589-600. https://doi.org/10.1079/bjn19780074

102. Xia Y, Hill KE, Byrne DW, Xu J, Burk RF (2005) Effectiveness of selenium supplements in a low-selenium area of China. Am J Clin Nutr 81(4):829-834. https://doi.org/10.1093/ajen/81.4.829

103. Zhou H, Wang T, Li Q, Li D (2018) Prevention of Keshan disease by selenium supplementation: a systematic review and metaanalysis. Biol Trace Elem Res 186(1):98-105. https://doi.org/10. 1007/s12011-018-1302-5

104. Zhu YH, Wang XF, Yang G, Wei J, Tan WH, Wang LX, Guo X, Lammi MJ, Xu JH (2019) Efficacy of long-term selenium supplementation in the treatment of chronic Keshan disease with congestive heart failure. Curr Med Sci 39(2):237-242. https:// doi.org/10.1007/s11596-019-2025-3

105. Stewart RDH, Griffiths NM, Thomson CD, Robinson MF (1978) Quantitative selenium metabolism in normal New Zealand women. Br J Nutr 40(1):45-54. https://doi.org/10.1079/bjn19 780094

106. Yang G, Gu L, Zhou R, Yin S (1989) Studies of human maximal and minimal safe intake and requirement of selenium. In: Wendel A (ed) Selenium in biology and medicine. Springer, Berlin, pp 223-229

107. Levander OA (1987) A global view of human selenium nutrition. Annu Rev Nutr 7:227-250. https://doi.org/10.1146/annurev.nu. 07.070187.001303

108. Yang GQ, Xia YM (1995) Studies on human dietary requirements and safe range of dietary intakes of selenium in China and their application in the prevention of related endemic diseases. Biomed Environ Sci 8(3): 187-201

109. Guo X, Ma WJ, Zhang F, Ren FL, Qu CJ, Lammi MJ (2014) Recent advances in the research of an endemic osteochondropathy in China: Kashin-Beck disease. Osteoarthritis Cartilage 22(11):1774-1783. https://doi.org/10.1016/j.joca.2014.07.023

110. Lian W, Liu H, Song Q, Liu YQ, Sun LY, Deng Q, Wang SP, Cao YH, Zhang XY, Jiang YY, Lv HY, Duan LB, Yu J (2018) Prevalence of hand osteoarthritis and knee osteoarthritis in Kashin-Beck disease endemic areas and non Kashin-Beck disease endemic areas: a status survey. PLoS ONE 13(1):e0190505. https://doi.org/10.1371/journal.pone.0190505

111. Wang X, Ning Y, Liu A, Qi X, Liu M, Zhang P, Guo X (2019) The systematic review and meta-analysis of X-ray detective rate of Kashin-Beck disease from 1992 to 2016. BMC Musculoskelet Disord 20:78. https://doi.org/10.1186/s12891-019-2461-z

112. White L, Romagné F, Müller E, Erlebach E, Weihmann A, Parra G, Andrés AM, Castellano S (2015) Genetic adaptation to levels of dietary selenium in recent human history. Mol Biol Evol 32(6):1507-1518. https://doi.org/10.1093/molbev/msv043

113. Ning YJ, Wang X, Ren L, Guo X (2013) Effects of dietary factors on selenium levels of children to prevent kashin-beck disease during a high-prevalence period in an endemic area: a cohort study. Biol Trace Elem Res 153:58-68

114. Wang Y, Crawford MA, Chen J, Li J, Ghebremeskel K, Campbell TC, Fan W, Parker R, Leyton J (2003) Fish consumption, 
blood docosahexaenoic acid and chronic diseases in Chinese rural populations. Comp Biochem Physiol A Mol Integr Physiol 136(1):127-140. https://doi.org/10.1016/s1095-6433(03)00016-3

115. Xia Y, Hill KE, Li P, Xu J, Zhou D, Motley AK, Wang L, Byrne DW, Burk RF (2010) Optimization of selenoprotein P and other plasma selenium biomarkers for the assessment of the selenium nutritional requirement: a placebo-controlled, double-blind study of selenomethionine supplementation in selenium-deficient Chinese subjects. Am J Clin Nutr 92(3):525-531. https://doi.org/10. 3945/ajen.2010.29642

116. Han F, Pang X, Wang Q, Liu Y, Liu L, Chai Y, Zhang J, Wang S, Lu J, Sun L, Zhan S, Wu H, Huang Z (2020) Dietary serine and sulfate-containing amino acids related to the nutritional status of selenium in lactating Chinese women. Biol Trace Elem Res. https://doi.org/10.1007/s12011-020-02204-w

117. Chinese Nutrition Society (2013) Chinese dietary reference intakes. The Science Press, Beijing

118. Mannes AM, Seiler A, Bosello V, Maiorino M, Con$\operatorname{rad}$ M (2011) Cysteine mutant of mammalian GPX4 rescues cell death induced by disruption of the wild-type selenoenzyme. FASEB J. https://doi.org/10.1096/fj.10-177147

119. Xu XM, Turanov AA, Carlson BA, Yoo MH, Everley RA, Nandakumar R, Sorokina I, Gygi SP, Gladyshev VN, Hatfield DL (2010) Targeted insertion of cysteine by decoding UGA codons with mammalian selenocysteine machinery. Proc Natl Acad Sci U S A 107(50):21430-21434. https://doi.org/10.1073/ pnas. 1009947107

120. Ingold I, Berndt C, Schmitt S, Doll S, Poschmann G, Buday K, Roveri A, Peng X, Porto Freitas F, Seibt T, Mehr L, Aichler M, Walch A, Lamp D, Jastroch M, Miyamoto S, Wurst W, Ursini F, Arnér ESJ, Fradejas-Villar N, Schweizer U, Zischka H, Friedmann Angeli JP, Conrad M (2018) Selenium utilization by GPX4 Is required to prevent hydroperoxide-induced ferroptosis. Cell 172(3):409-422.e21. https://doi.org/10.1016/j.cell.2017.11.048

121. Turanov AA, Everley RA, Hybsier S, Renko K, Schomburg L, Gygi SP, Hatfield DL, Gladyshev VN (2015) Regulation of selenocysteine content of human selenoprotein $P$ by dietary selenium and insertion of cysteine in place of selenocysteine. PLoS ONE 10(10):e0140353. https://doi.org/10.1371/journal.pone.0140353

122. Wang $Q$ et al (2016) The synergistic effect of serine with selenocompounds on the expression of SelP and GPx in HepG2 Cells. Biol Trace Elem Res 173(2):291-296

123. 詹硕, 等等。硒代蛋氨酸对肝细胞L02中硒蛋白表达的影响 及丝氨酸的协同作用。卫生㸴究, 2021,50(1): 100-103

124. Zhou L et al (2021) Serine supplementation in the diets of late gestating and lactating sows improves selenium nutritional status in sows and their offspring. Biol Trace Elem Res. https://doi.org/ 10.1007/s12011-021-02661-x

125. Han $\mathrm{F}$ et al (2020) Dietary serine and sulfate-containing amino acids related to the nutritional status of selenium in lactating Chinese women. Biol Trace Elem Res. https://doi.org/10.1007/ s12011-020-02204-w

126. Ganther HE (1979) Metabolism of hydrogen selenide and methylated selenides. Adv Nutr Res. https://doi.org/10.1007/ 978-1-4613-9931-5_5

127. Suzuki KT, Ogra Y (2002) Metabolic pathway for selenium in the body: speciation by HPLC-ICP MS with enriched Se. Food Addit Contam 19(10):974-983. https://doi.org/10.1080/02652 030210153578

128. Jackson MI, Lunøe K, Gabel-Jensen C, Gammelgaard B, Combs GF Jr (2013) Metabolism of selenite to selenosugar and trimethylselenonium in vivo: tissue dependency and requirement for S-adenosylmethionine-dependent methylation. J Nutr Biochem 24(12):2023-2030. https://doi.org/10.1016/j.jnutbio.2013. 04.007
129. Sen N, Cross AM, Lorenzi PL, Khan J, Gryder BE, Kim S, Caplen NJ (2018) EWS-FLI1 reprograms the metabolism of Ewing sarcoma cells via positive regulation of glutamine import and serine-glycine biosynthesis. Mol Carcinog 57(10):13421357. https://doi.org/10.1002/mc.22849

130. Ramos RJ, Pras-Raves ML, Gerrits J, van der Ham M, Willemsen M, Prinsen H, Burgering B, Jans JJ, Verhoeven-Duif NM (2017) Vitamin B6 is essential for serine de novo biosynthesis. J Inherit Metab Dis 40(6):883-891. https://doi.org/10.1007/ s10545-017-0061-3

131. Puglisi R, Maccari I, Pipolo S, Conrad M, Mangia F, Boitani C (2012) The nuclear form of glutathione peroxidase 4 is associated with sperm nuclear matrix and is required for proper paternal chromatin decondensation at fertilization. $\mathrm{J}$ Cell Physiol 227(4):1420-1427. https://doi.org/10.1002/jcp. 22857

132. Zhou JC, Zheng S, Mo J, Liang X, Xu Y, Zhang H, Gong C, Liu XL, Lei XG (2017) Dietary selenium deficiency or excess reduces sperm quality and testicular mRNA abundance of nuclear glutathione peroxidase 4 in rats. J Nutr 147(10):19471953. https://doi.org/10.3945/jn.117.252544

133. Schneider M, Förster H, Boersma A, Seiler A, Wehnes H, Sinowatz F, Neumüller C, Deutsch MJ, Walch A, Hrabé de Angelis M, Wurst W, Ursini F, Roveri A, Maleszewski M, Maiorino M, Conrad M (2009) Mitochondrial glutathione peroxidase 4 disruption causes male infertility. FASEB J 23(9):3233-3242. https://doi.org/10.1096/fj.09-132795

134. Andersen OM, Yeung $\mathrm{CH}$, Vorum $\mathrm{H}$, Wellner M, Andreassen TK, Erdmann B, Mueller EC, Herz J, Otto A, Cooper TG, Willnow TE (2003) Essential role of the apolipoprotein E receptor-2 in sperm development. J Biol Chem 278(26):23989-23995. https://doi.org/10.1074/jbc.M302157200

135. Brütsch SH, Wang CC, Li L, Stender H, Neziroglu N, Richter C, Kuhn H, Borchert A (2015) Expression of inactive glutathione peroxidase 4 leads to embryonic lethality, and inactivation of the Alox 15 gene does not rescue such knock-in mice. Antioxid Redox Signal 22(4):281-293. https://doi.org/10.1089/ars.2014. 5967

136. Brütsch SH, Rademacher M, Roth SR, Müller K, Eder S, Viertel D, Franz C, Kuhn H, Borchert A (2016) Male subfertility induced by heterozygous expression of catalytically inactive glutathione peroxidase 4 is rescued in vivo by systemic inactivation of the Alox15 gene. J Biol Chem 291(45):23578-23588. https:// doi.org/10.1074/jbc.M116.738930

137. Ingold I, Aichler M, Yefremova E, Roveri A, Buday K, Doll S, Tasdemir A, Hoffard N, Wurst W, Walch A, Ursini F, Friedmann Angeli JP, Conrad M (2015) Expression of a catalytically inactive mutant form of glutathione peroxidase 4 (GPX4) confers a dominant-negative effect in male fertility. J Biol Chem 290(23):14668-14678. https://doi.org/10.1074/jbc.M115.656363

138. Wang Q et al (2011) Low-Se diet can affect sperm quality and testicular glutathione peroxidase- 4 activity in rats. Biol Trace Elem Res. https://doi.org/10.1007/s12011-020-02515-y

139. Schomburg L, Riese C, Michaelis M, Griebert E, Klein MO, Sapin R, Schweizer U, Köhrle J (2006) Synthesis and metabolism of thyroid hormones is preferentially maintained in seleniumdeficient transgenic mice. Endocrinology 147(3):1306-1313. https://doi.org/10.1210/en.2005-1089

140. Lin SL, Wang CW, Tan SR, Liang Y, Yao HD, Zhang ZW, Xu SW (2014) Selenium deficiency inhibits the conversion of thyroidal thyroxine (T4) to triiodothyronine (T3) in chicken thyroids. Biol Trace Elem Res 161(3):263-271. https://doi.org/10.1007/ s12011-014-0083-8

141. Valea A, Georgescu CE (2018) Selenoproteins in human body: focus on thyroid pathophysiology. Hormones (Athens) 17(2):183-196. https://doi.org/10.1007/s42000-018-0033-5 
142. Thompson KM, Haibach H, Sunde RA (1995) Growth and plasma triiodothyronine concentrations are modified by selenium deficiency and repletion in second-generation selenium-deficient rats. J Nutr 125(4):864-873. https://doi.org/10.1093/jn/125.4.864

143. Jianhua H, Ohtsuka A, Hayashi K (2000) Selenium influences growth via thyroid hormone status in broiler chickens. Br J Nutr 84(5):727-732

144. Phiri FP, Ander EL, Bailey EH, Chilima B, Chilimba ADC, Gondwe J, Joy EJM, Kalimbira AA, Kumssa DB, Lark RM, Phuka JC, Salter A, Suchdev PS, Watts MJ, Young SD, Broadley MR (2019) The risk of selenium deficiency in Malawi is large and varies over multiple spatial scales. Sci Rep 9(1):6566. https:// doi.org/10.1038/s41598-019-43013-z

145. Rayman MP, Thompson AJ, Bekaert B et al (2008) Randomized controlled trial of the effect of selenium supplementation on thyroid function in the elderly in the United Kingdom. Am J Clin Nutr 87:370-378. https://doi.org/10.1093/ajen/87.2.370

146. Han F et al (20213) Low-selenium intake is associated with postpartum weight retention in Chinese women and impaired physical development of their offsprings. Br J Nutr. https://doi.org/10. 1017/S0007114521000015

147. Hoffmann PR (2007) Mechanisms by which selenium influences immune responses. Arch Immunol Ther Exp (Warsz) 55(5):289297. https://doi.org/10.1007/s00005-007-0036-4

148. Huang Z, Rose AH, Hoffmann PR (2012) The role of selenium in inflammation and immunity: from molecular mechanisms to therapeutic opportunities. Antioxid Redox Signal 16(7):705-743. https://doi.org/10.1089/ars.2011.4145

149. Avery JC, Hoffmann PR (2018) Selenium, selenoproteins, and immunity. Nutrients 10(9):1203. https://doi.org/10.3390/nu100 91203

150. Ma C, Hoffmann PR (2020) Selenoproteins as regulators of T cell proliferation, differentiation, and metabolism. Semin Cell Dev Biol S1084-9521(20):30173-30177. https://doi.org/10.1016/j. semcdb.2020.11.006

151. Guillin OM, Vindry C, Ohlmann T, Chavatte L (2019) Selenium, selenoproteins and viral infection. Nutrients 11(9):2101. https:// doi.org/10.3390/nu11092101

152. Bermano G, Méplan C, Mercer DK, Hesketh JE (2020) Selenium and viral infection: are there lessons for COVID-19? Br J Nutr 6:1-10. https://doi.org/10.1017/S0007114520003128
153. Chen J, Geissler C, Parpia B, Li J, Campbell TC (1992) Antioxidant status and cancer mortality in China. Int $\mathrm{J}$ Epidemiol 21(4):625-635. https://doi.org/10.1093/ije/21.4.625

154. Lauretani F, Semba RD, Dayhoff-Brannigan M, Corsi AM, Di Iorio A, Buiatti E, Bandinelli S, Guralnik JM, Ferrucci L (2008) Low total plasma carotenoids are independent predictors of mortality among older persons: the InCHIANTI study. Eur J Nutr 47(6):335-340. https://doi.org/10.1007/s00394-008-0732-9

155. Zhang L, Zeng H, Cheng WH (2018) Beneficial and paradoxical roles of selenium at nutritional levels of intake in healthspan and longevity. Free Radic Biol Med 1(127):3-13. https://doi.org/10. 1016/j.freeradbiomed.2018.05.067

156. Yim SH, Clish CB, Gladyshev VN (2019) Selenium deficiency is associated with pro-longevity mechanisms. Cell Rep 27(9):27852797.e3. https://doi.org/10.1016/j.celrep.2019.05.001

157. Wu RT, Cao L, Mattson E, Witwer KW, Cao J, Zeng H, He X, Combs GF Jr, Cheng WH (2017) Opposing impacts on healthspan and longevity by limiting dietary selenium in telomere dysfunctional mice. Aging Cell 16(1):125-135. https://doi.org/10. 1111/acel.12529

158. Robberecht H, De Bruyne T, Davioud-Charvet E, Mackrill J, Hermans N (2019) Selenium status in elderly people: longevity and age-related diseases. Curr Pharm Des 25(15):1694-1706. https://doi.org/10.2174/1381612825666190701144709

159. Zhang R, Wang L, Li Y, Li H, Xu Y (2020) Distribution characteristics of rare earth elements and selenium in hair of centenarians living in China longevity region. Biol Trace Elem Res 197(1):15-24. https://doi.org/10.1007/s12011-019-01970-6

160. Giovannini S, Onder G, Lattanzio F, Bustacchini S, Di Stefano G, Moresi R, Russo A, Bernabei R, Landi F (2018) Selenium concentrations and mortality among community-dwelling older adults: results from IlSIRENTE study. J Nutr Health Aging 22(5):608-612. https://doi.org/10.1007/s12603-018-1021-9

Publisher's Note Springer Nature remains neutral with regard to jurisdictional claims in published maps and institutional affiliations. 